\title{
Demokrasi di Malang Menggali Kontribusi Masyarakat Sipil Dalam Pengembangan
} Demokrasi Lokal

\author{
Ratnaningsih Damayanti ${ }^{1)}$ *, Rachmad Gustomy ${ }^{2)}$, Muhtar Haboddin ${ }^{3)}$ \\ ${ }^{1,2,3}$ Program Studi Ilmu Pemerintahan, Fakultas Ilmu Sosial dan Ilmu Politik, Universitas \\ Brawijaya. Jl Veteran malang, Jawa Timur, Tepn. (0341) 575755, ext. 121 \\ * Korespondensi Penulis. E-mail: ratnaningsih86@gmail.com
}

\begin{abstract}
Abstrak
Hampir 2 (dua) dekade setelah masa reformasi perlu dilihat kembali bagaimana peran masyarakat sipil dalam pengembangan demokrasi, khususnya demokrasi lokal. Penelitian ini berfokus pada konstribusi masyarakat sipil dalam demokrasi di Malang. Tujuan penelitian ini adalah untuk menggali kontribusi mereka dalam pengembangan demokrasi lokal. Konsepsi masyarakat sipil yang dipergunakan ialah masyarakat sipil versi Alexis de Tocqueville, yaitu masyrakat sipil sebagai asosiasi sukarela untuk membatasi kekuasaan negara. Metode penelitian yang dipergunakan adalah metode kualitatif. Hasil yang didapatkan dari penelitian ini adalah masyarkat sipil di Kota Malang dikelompokkan kedalam 6 isu utama, yaitu penanganan terhadap anak jalanan, isu kesehatan, isu pemerintahan, isu perempuan, dan isu buruh, dan isu pendidikan. Kontribusi masyarakat sipil dalam demokrasi di Kota Malang adalah Pertama, mereka menyediakan basis pembatas kekuasaan negara. Kedua, masyarakat sipil melengkapi peran partai politik dalam mendorong partisipasi, meningkatkan efektifitas dan ketrampilan berdemokrasi serta mendorong pemahaman tentang kewarganegaraan. Ketiga, membangun saluran di luar partai politik untuk mengartikulasikan, menampung dan merepresentasikan kepentingan perempuan, buruh, dan kelompok marginal seperti LGBT dan anak jalanan.
\end{abstract}

Kata kunci: Masyarakat Sipil; Demokrasi; Malang

\section{Democracy in Malang: the Contribution of Civil Society in Developing Local Democaracy}

\begin{abstract}
Nearly two decades after the government reform needs to be seen again at how the role of civil society in the development of democracy, specially local democracy. This study focuses on the contribution of civil society in the development of democracy in Malang. The purpose of this study is to seek civil society contribution in the development of local democracy. Conception of civil society that is used is the civil society version of Alexis de Tocqueville, that is civil society as a voluntary association. The research method used is a qualitative method. The results obtained from this study is the civil society in Malang grouped into six major issues, that are street children, health, development and governance, women, labor, and education issues. The contribution of civil society in a democracy in Malang is firstly, they provide the basis of state power divider. Second, civil society complements the role of political parties in encouraging participation, increase the effectiveness and democratic skills and encourage understanding of citizenship. Third, building a channel outside the political parties to articulate, accommodating and representing the interests of women, workers, and marginal groups such as LGBT and street children.
\end{abstract}

Keywords: Civil Society; Local Democracy; Malang. 


\section{PENDAHULUAN}

Perjalanan yang dilakukan oleh Alexis de Tocqueville di Amerika pada awal abad ke-19 membuahkan tulisan Democracy in America yang menjadi rujuan utama bagi studi mengenai masyarakat sipil (civil society) di berbagai negara. Kajian Tocqueville tentang masyarakat sipil masih menjadi rujukan dan masih relevan dalam melihat pertumbuhan masyarakat sipil Indonesia kontemporer. Menariknya lagi adalah Tocqueville 'memahami masyarakat sipil sebagai fenomena asosiasional' dalam sebuah negara.

Cara berpikir Tocqueville ini menempatkan masyarakat sipil berada di luar negara. Dalam bahasa politik biasa disebut cara pandangnya masyarakat. Studi yang dilakukan oleh Amy Risley (2015) menyebutkan bahwa di Amerika Latin, masyarakat sipil terlibat dalam berbagai kegiatan politik seperti advokasi, pembuatan keputusan, lobbiying, dan partnership. Hal yang sama juga terjadi pada konteks Mesir. Sejarah Mesir memperlihatkan bagaimana kehidupan masyarakatnya yang sudah lebih dari 50 tahun dipimpin oleh penguasa militer. Dalam kondisi seperti ini, masyarakat sipil justru terhalang untuk ikut serta dalam upaya demokratisasi. Hal ini bisa terjadi karena terlalu banyak aturan yang menjadi rintangan untuk melakukan kerja-kerja advokasi dan pemberdayaan. Kondisi ini menyebabkan mereka melakukan gerakan sosial melalui asosiasi-asosiasi sukarela yang tergolong dalam asosiasi profesi dan serikat buruh (El Medni, 2013).

Sementara di Filipina, masyarakat sipilnya mengalami krisis akuntabilitas karena mereka sangat tergantung dengan pendanaan dari lembaga donor negeri (Lowry, 2008). Hal ini menjadi penting karena masyarakat sipil memerlukan pendanaan untuk kerja-kerja mereka dalam mendorong proses demokratisasi. Agenda demokratisasi yang selama ini diperankan masyarakat sipil beririsan dengan agenda para lembaga donor. Artinya, lembaga donor sangat berkuasa untuk mempengaruhi pekerjaan masyarakat sipil. Inilah fenomena yang terjadi. Kendatipun demikian kolaborasi masyarakat sipil dengan lembaga donor tidak selalu seirama. Dikatakan demikian karena kadang-kala agenda yang dibawa oleh lembaga donor tidak sama dengan kebutuhan masyarakat setempat.

Sementara tulisan Lisa Jordan dan Peter Van Tuijl (2006) mencoba mengkaji persoalan fundamental LSM. Buku ini secara spesifik bertutur tentang perlunya akuntabilitas dalam tubuh LSM. Negaranegara yang menjadi sorotan dalam karya ini adalah China, Uganda, dan Indonesia. Akuntabilitas LSM ataupun masyarakat sipil menjadi persoalan penting untuk diperhatikan karena selama ini masyarakat sipil tidak pernah melakukan akuntabilitas kepada masyarakat dampingannya.

Pada wilayah dalam negeri, studi mengenai masyarakat sipil dipopulerkan oleh Mansour Fakih (1996) yang berhasil memetakan ideologi masyarakat sipil pada masa pemerintahan Orde Baru. Setelah Orde Baru runtuh, Verena Beittinger-Lee dalam publikasinya (Un) Civil Society and Political Change in Indonesia memaparkan bahwa setelah rezim Soeharto berakhir, masyarakat sipil memiliki banyak kelemahan sehingga tidak mampu memainkan peran 
konstruktif yang berjangka panjang dalam perselisihan politik. Setelah reformasi justru muncul uncivil society yang menyebabkan munculnya konflik agama dan etnis, kekerasan di berbagai daerah sehingga membuat masyarakat takut. Hal ini membuat negara menjadi lemah.

Sejatinya, demokrasi tidak hanya bergerak dalam level nasional, tetapi juga pada level lokal. Pada tingkat lokal tidak dapat dipungkiri terdapat raja-raja kecil yang menjalankan sistem non-demokrasi. Desentralisasi telah memberikan peluang bagi raja-raja kecil dan patron di tingkat lokal untuk mempertahankan sistem klientelisme (Rahayu dan Trisnanto, 2016). Sistem klintelisme dalam batasan tertentu semakin tumbuh subur dan berkembang di tingkat. Hal ini bisa terjadi karena lemahnya kontrol dari masyarakat sipil terhadap pemerintahan lokal.

Sistem demokrasi mengharuskan terwujudnya pemerintahan yang responsif terhadap kebutuhan masyarakat. Pada era desentralisasi dan otonomi daerah seperti sekarang, peran pemerintah daerah lebih besar daripada pemerintah pusat dalam melayani masyarakat. Dalam konteks Malang masyarakat yang berada di wilayah ini merupakan masyarakat plural yang terbagi dalam berbagai kelompok. Tidak semua kelompok bisa tersentuh oleh pemerintah daerah, khususnya kelompok marginal seperti penyandang cacat, mantan pengguna narkoba, transeksual, homoseksual, masyarakat miskin, anak jalanan, dan lain sebagainya. Kealfaan pemerintah daerah, memberikan ruang kepada penggiat masyarakat sipil untuk memberikan akses kepada mereka untuk mendapatkan pelayanan yang merupakan haknya.

Menurut data BAKESBANGPOL Kota Malang tahun 2014, di kota ini terdapat 139 organisasi masyarakat (ormas). Masyarakat sipil harus mendaftarkan diri menjadi organisasi masyarakat di badan ini untuk mendapatkan legalisasi/ijin dari pemerintah kota. Ratusan Masyarakat sipil tersebut bergerak dengan sasaran yang berbeda-beda dan ideologi yang berbeda juga. Karena itu dengan mengangkat penelitian, maka kehadiran dan kiprah masyarakat sipil di Kota Malang bisa terungkap sosok dan aktivitas dalam melakukan kerja-kerja sosialnya.

Korelasi yang positif antara demokrasi dan masyarakat sipil (civil society) ditunjukkan oleh Mohtar Mas'oed (2002) bahwa demokrasi sendiri tidak akan bisa ditegakkan bila tidak didukung oleh kekuatan civil society dan civil society akan menjadi kacau jika demokrasi tidak segera diwujudkan. Demokrasi bisa ditegakkan dengan dukungan civil society, begitu pula sebaliknya. Hal ini mengisyaratkan bahwa demokrasi selalu membutuhkan aktor civil society. Kalau demikian penjelasannya, maka keberadaan civil society sangat diperlukan dalam membangun sistem politik yang demokrasi.

Pembahasan mengenai masyarakat sipil bukanlah hal yang dimulai pada abad 20, tetapi jauh sebelum masehi. Pada masa Yunani kuno, masyarakat sipil dipahami sebagi ruang pribadi (terpisah dari ruang politik) yang terdiri dari perempuan dan budak. Artinya, masyarakat sipil adalah kelas selain zoon politicon. Ia tidak memiliki kedudukan yang tinggi dalam masyarakat, tidak 
terlibat dalam kegiatan politik, dan merupakan kelas yang mementingkan dunia pribadi yang sangat berbeda dengan masyarakat politik.

Beberapa ratus tahun kemudian, ketika Thomas Hobbes dan John Locke menawarkan teorinya tentang negara, mereka menjelaskan bahwa masyarakat sipil adalah masyarakat yang melakukan kontrak sosial dengan negara. Mereka harus rela diatur dan tunduk kepada negara karena negara memiliki tujuan yang baik, yaitu menyelamatkan masyarakat sipil dari sifat jahat mereka sendiri. Pada masa ini pembagian antara ranah negara dengan masyarakat sipil sudah jelas.

Pembagian antara ranah negara dengan masyarakat sipil sebenarnya bukanlah monopoli dari pemikiran Hobbes dan Locke. Pemikiran politik kontemporer, Alfred Stepan (1996) dalam salah satu karya juga menjelaskan relasi negara, masyarakat sipil dan masyarakat politik.

Negara didefinisikan sebagai administratif, legal, birokratis, dan koersif yang berkesinambungan dan berusaha mengelola aparat negara, menyusun hubungan antara kekuasaan sipil dan pemerintah, dan menyusun hubungan dalam masyarakat politik dan civil society. Masyarakat sipil adalah arena tempat berbagai gerakan sosial serta organisasi sipil dari semua kelas berusaha menyatakan diri mereka dalam suatu himpunan dapat mengespresikan diri dan memajukan berbagai kepentingan. Selanjutnya, masyarakat politik dimaknai sebagai arena tempat masyarakat bernegara mengatur diri secara khusus dalam kontestasi politik untuk memper- oleh kontrol atas pemerintah dan aparat negara.

Nampak jelas perbedaan antara ranah negara, masyarakat sipil, dan masyarakat politik. Ketiga institusi ini memilih ruang lingkup dan cakupan wilayah kerja yang berbeda-berbeda. Sedangkan pandangan Adam Smith tentang masyarakat sipil juga patut dicatat. Bagi Smith, masyarakat sipil sebagai individu-individu yang saling berinteraksi untuk memenuhi kebutuhan mereka melalui mekanisme pasar. Sikap individu yang bersosialisasi untuk memenuhi kebutuhan menunjukkan adanya sipilitas. Sipilitas dimaknai sebagai simpati yang ditunjukkan pada orang lain untuk menengai self love mereka. Fenomena ini bersifat subjektif.

Perkembangan konsepsi masyarakat sipil yang terakhir adalah masyarakat sipil dipahami sebagai ruang asosiasi sukarela. Urgensi asosiasi berakar pada pemikiran liberal untuk membatasi kekuasaan negara. Demokrasi modern dianggap berpotensi untuk memunculkan depotisme demokrasi. Negara terjamin legitimasinya melalui proses pemilihan, memiliki kekuasaan atas orang lain yang telah memilihnya. Akibatnya, lembaga sosial dilumpuhkan oleh lembaga politik. Demokrasi yang ada dalam masyarakat dilumpuhkan oleh mekanisme administratif dan politis dari negara. Masyarakat sipil memberi kekuasaan pada negara sekaligus menjadi korban kekuasaan tersebut (Chandoke, 2002: 115-161). Dalam bahasa Tocqueville disebut "the formal institutions of democracy and capitalism left individuals helpless against the electoral power of the majority as expressed through the actions of the State" 
Untuk mengatasi potensi tirani ini Tocqueville menawarkan tiga macam cara, yaitu pertama, mendistribusikan kekuasaan ke berbagai lembaga pemerintahan. Kedua, menyelenggarakan pemilihan secara periodik untuk mencegah monopoli. Ketiga, mengontrol lembaga kekuasaan oleh asosiasi sukarela. Asosiasi-asosiasi sosial, kultural, profesional, dan religius dalam masyarakat sipil memiliki kapasitas untuk menjaga kekuasaan negara di bawah kontrolnya. Asosiasi sukarela ini oleh Tocqueville disebut berpedan sebagai independent eye of society yaitu dengan memberikan kontrol kepada negara melalui kehidupan sehari-hari. Asosiasi sukarela mengikat individuindividu di dalamnya melalui hubunganhubungan mikro. Hal ini dapat memunculkan solidaritas dan kewaspadaan terhadap persoalan-persoalan yang mereka hadapi.

Asosiasi sukarela merupakan jawaban atas dilema liberalisme. Asosiasi sukarela berbasis pada prinsip kebebasan atau kesukarelaan untuk memilih. Dengan kata lain tidak boleh ada paksaan dari individu untuk mengikuti asosiasi ini. Asosiasi sukarela merangkul individu yang terisolasi sehingga asosiasi ini dapat dijadikan sebagai alat individu untuk mencapai kepentingannya serta belajar untuk mengidentifikasikan diri dengan komunitas. Pluralitas dalam asosiasi sukarela adalah alat untuk mempertemukan kepentingan pribadi dan kepentingan publik sekaligus jaminan melawan penyelenggaraan kekuasaan secara penuh oleh negara. Pluralitas menurut de Tocqueville adalah jaminan terbaik dari demokrasi (Chandoke, 2002: 162-163.
Penelitian ini terinspirasi dari karya Tocqueville "Democracy in American" yang berbasis pengamatannya di Amerika pada 1831-1832. Menurutnya, keberhasilan demokrasi di Amerika tidak hanya terletak pada mekanisme pembagian kekuasaan pada negara, tetapi juga pada kemampuan masyarakatnya membangun asosiasi-asosiasi sukarela yang mandiri dan mampu membatasi kekuasaan negara dalam kehidupan sehari-hari.

Keberadaan asosiasi sukarela yang kuat akan mengisi aspek-aspek yang tidak bisa dijalankan oleh negara dalam level mikro. Keberadaan asosiasi sukarela ini menciptakan inisiatif sosial dan kemandirian yang tinggi. Demokrasi seharusnya tidak hanya menciptakan pemerintahan yang cakap, tetapi juga menciptakan asosiasi-asosiasi sukarela yang mampu mendorong aktivitas sosial yang pada akhirnya mampu menciptakan kontrol terhadap kekuasaan negara.

Sedangkan ilmuwan politik dari LIPI, AS Hikam (1996:3) mendefinisikan masyarakat sipil atau civil society sebagai wilayah-wilayah kehidupan sosial yang terorganisasi dan bercirikan antara lain kesukarela (voluntary), keswasembadaan (self generating), keswadayaan (self supproting), kemandirian tinggi terhadap negara, dan taat hukum. Menurutnya, ada dua arena penting masyarakat sipil, yaitu menyatakan ekspresi diri dalam bentuk organiasi sipil yang bebas dan otonom dan menyatakan diri dalam bentuk kebebasan berpendapat. Hal ini dikarenakan pada dasarnya masyarakat sipil berusaha untuk mengimbangi hegemoni negara dan memperkokoh posisi dan kemandirian masyarakat. Pandangan ini berpijak pada tradisi 
model Eropa Timur, dimana kehadiran masyarakat sipil semata-mata diorientasikan untuk menentang kehadiran Negara (Mas'oed, 2002: 152).

Asosiasi sukarela memberikan kontribusi pada perkembangan demokrasi. Asosiasi sukarela membuat individu saling berinteraksi satu sama lain dan menjaga kebebasan berserikat dan berkumpul. "feelings and opinions are recruited, the heart is enlarged, and the human mind is developed only by the reciprocal influence of men upon one another (Tocqueville)".

Asosiasi sukarela adalah wadah keberadaban, sehingga apabila masyarakat ingin menjadi beradab, maka jalan yang terbaik adalah menumbuhkan seni berasosiasi. Asosiasi-asosiasi sukareka merupakan wadah pengembangan nilai-nilai kewargaan yang berbasis pada kemandirian dan ketaatan hukum serta ditujukan untuk menciptakan public goods. Kemandirian dan ketaatan hukum sangatlah dijunjung tinggi atas keberadaan masyarakat sipil dalam negara demokrasi.

Mansour Fakih (1996) merupakan generasi awal yang memiliki konsentrasi dalam mengamati masyarakat sipil di Indonesia. Dalam bukunya yang bertajuk Masyarakat Sipil untuk Transformasi Sosial, ia mengelompokkan paradigma masyarakat sipil di Indonesia ke dalam tiga kelompok, yaitu konformisme, reformasi, dan transformisme. Pertama, masyarakat sipil tipe konformis bekerja berdasarkan kepada paradigma bantuan karitatif, berorientasi pada proyek, dan bekerja sebagai organisasi yang menyesuaikan diri dengan sistem dan struktur yang ada. Motivasi utama program mereka adalah menolong rakyat miskin.

Kedua, masyarakat sipil tipe reformis ini dipengaruhi oleh ideologi modernisasi dan developmentalisme. Tema mereka adalah meningkatkan partisipasi masyarakat dalam pembangunan. Korupsi yang terjadi di pemerintahan dianggap sebagai sebab utama "keterbelakangan" yang terjadi di masyarakat. Ketiga, masyarakat sipil tipe transformatif mempertanyakan paradigma mainstream yang ada dan ideologi yang tersembunyi di dalamnya. Mereka berusaha mencari paradigma alternatif yang menyebabkkan persoalan-persoalan sesial ekonomi politik di masyarakat. Caranya adalah dengan melakukan pendidikan politik rakyat untuk memunculkan keadaan kritis sebagai jalan masuk perubahan.

Tiga tipe kelompok masyarakat sipil tersebut merupakan hasil studi yang dilakukan Mansour Fakih pada berbagai masyarakat sipil di Indonesia dari masa Orde Baru. Pengelompok ini berpijak pada corak dan bentuk ideologi masyarakat sipil ketika melakukan kerja advokasi di lapangan. Pilihan politik masyarakat dalam memerankan diri apabila sebagai konformisme, reformasi, dan transformisme bisa dibaca sebagai strategi mereka untuk survival dalam konteks politik Orde Baru yang terkenal sentralistik represif dan menerapkan sistem politik korporatisme.

Studi masyarakat sipil selanjutnya tidak lagi bertitik-tolak pada pengelompokkan sebagaimana ditulis Mansour Fakih. Hasil pengamatan Suharko (2005: 282) menunjukkan bahwa atmosfir politik yang terbuka dan demokratis paska Orde Baru semakin 
membuka kesempatan politik bagi masyarakat sipil untuk lebih terlibat aktif dalam upaya-upaya pengembangan pemerintahan demokratik. Kajian yang dilakukan Agus Sudibyo mengatakan sejauh ini, sudah terlanjur, mapan pandangan yang menempatkan masyarakat sipil sebagai kekuatan yang lahir untuk mengimbangi dan mengontrol kekuasaan negara (2010: 23). Apa yang disampaikan Suharko maupun Sudibyo menunjukkan bahwa peran masyarakat sipil pasca tumbangnya Orde Baru semakin dalam, dan bahkan dalam level tertentu bisa menjadi kekuatan mengimbang negara.

Menempatkan masyarakat sipil sebagai 'pengimbang' kekuatan masyarakat memiliki yang kokoh dalam diskursus politik. Hal ini bisa terjadi manakala negara dalam posisi lemah. Pasca Orde Baru pondasi pemerintahan sangat lemah. Kelemahan ini kemudian menjadi pintu masuk hadirnya kekuatan masyarakat sipil. Salah satu wacana dominan yang dikembangkan Bank Dunia menurut analisis Mohtar Mas'oed (2002) adalah memperkuat civil society. Tujuannya adalah agar masyarakat sipil bisa menjadi sarana untuk memangkas peran negara.

Cara berpikir liberal dengan memangkas peran negara, dan pada saat yang sama memperkuat kekuatan masyarakat sipil menjadi arus-utama dalam diskursus politik reformasi. Sementara M AS Hikam (1996) mencoba mengaitkan demokrasi dan civil society melalui pelacakan asal-usul dan kemungkinannya dalam konteks Indonesia. Sedangkan karya Thohir Luth (2002: 196) secara khusus memperlihatkan peran masyarakat sipil dalam mem- berikan solusi damai perbedaan dalam konteks keagamaan. Bagi Luth membangun masyarakat sipil berarti menyadarkan semua manusia untuk hidup dan bergaul dengan segala aktivitas dengan menggunakan agama sebagai tolak-ukur dalam kehidupan bernegara.

Larry Diamond (1994) juga menyebutkan keterkaitan masyarakat sipil dengan pertumbuhan demokrasi tingkat lokal. Pertama, mereka menyediakan basis pembatas kekuasaan negara. Kedua, masyarakat sipil melengkapi peran partai politik dalam mendorong partisipasi, meningkatkan efektifitas dan ketrampilan berdemokrasi serta mendorong pemahaman tentang kewarganegaraan. Ketiga, mengembangkan proyek demokratisasi lewat pendidikan politik. Keempat, Membangun saluran di luar partai politik untuk mengartikulasikan, menampung dan merepresentasikan kepentingan, khususnya untuk menyediakaan akses bagi kelompok-kelompok marjinal seperti orang miskin, perempuan, ras/etnis minoritas, dan lain-lain.

Kelima, mendorong transisi dari clientilism ke citizenship terutama di tingkat lokal karena seringkali demokratisasi bergerak di level nasional tapi otoritarianisme masih hidup di level lokal. Keenam, masyarakat sipil yang kuat dan pluralis bisa meminimalisasi polaritas konflik dalam masyarakat. Mereka menjadi jembatan yang yang memersatukan pemilahan kelas, etnis, agama, partisan terutama ketika menghadapi kekuasaan otoriter negara. Ketujuh, menjalankan rekrutmen dan melatih pemimpin politik baru. Kedelapan, memantau proses politik, khususnya pemilu. Kesembilan, menjalan-kan fungsi 
penyebaran informasi, terutama tentang aktifitas pemerintah. Kesepuluh, membangun modal sosial di tingkat grassroot untuk bekerjasama mengatasi persoalan publik sehingga memperkuat fondasi demokrasi. Kesebelas, sebagai rangkuman dari semua fungsi di atas, masyarakat sipil berfungsi untuk membangun kebebasan berserikat di kalangan masyarakat.

\section{METODE}

Metode penelitian yang dipergunakan adalah metode kualitatif. Penelitian kualitatif merupakan penelitian yang bermaksud memahami fenomena tentang apa yang dialami oleh subjek penelitian, misalnya perilaku, persepsi, motivasi, tindakan, dan lain-lain secara holistik, dan dengan cara deskripsi dalam bentuk kata-kata dan bahasa, pada suatu konteks khusus yang ilmiah dan dengan memanfaatkan berbagai metode ilmiah (Moleong, 2004: 6). Jenis penelitian yang dipergunakan adalah jenis penelitian deskriptif. Penelitian deskriptif mencari fakta dengan interpretasi yang tepat (Whitney dalam Andi Prastowo, 2011:201). Dengan metode ini, fenomena-fenomena yang terjadi pada masyarakat sipil seperti bagaimana mereka men-jalankan programnya, bagaimana mereka berjejaring, bagaimana memilih dan menanggapi isuisu lokal dan nasional, dan lain sebagainya akan diteliti dan diinterpretasikan.

Data yang dipergunakan adalah data primer yang diperoleh melalui wawancara. Data primer ini diperoleh dari informan kunci seperti, para pengurus LSM dan aktivis organisasi sukarela. Informan ini sangat diperlukan argumen- tasi ataupun tanggapannya dalam memberikan pendapat ataupun kesaksian karena mereka adalah aktor yang terlibat secara langsung dalam kegiatan ini.

Penelitian ini mewawancarai 15 aktivis organisasi sukarela yang ada di Kota Malang. Informan diperoleh dari Yayasan Sadar Hati, Jaringan Kemanusiaan Jawa Timur (JKJT), Malang Corruption Watch (MCW), Perkumpulan Pusat dan Informasi Regional (PATTIRO) Malang, Save Street Child, In Trans Institute, Sahabat Anak Kanker Malang, Mitra Wanita Pekerja Rumah Indonesia (MWPRI), Lembaga Pendidikan Sosial Ibu Pertiwi (LPS IP), Pusat Pengembangan Otonomi Daerah (PP Otoda), DPC Konfederasi Serikat Pekerja Seluruh Indonesia, RUMPUN, LKSA Harapan Umat, Aliansi Masyarakat Miskin Malang, dan LPAN Griya Baca. Pencarian data dilakukan pada tahun 2016 dengan mengerahkan asisten peneliti.

\section{HASIL DAN PEMBAHASAN}

Dari kelima belas asosiasi sukarela yang diteliti, peneliti mengelompokkan kelahiran lembaga yang dalam konteks penelitian ini disebut masyarakat sipil ke dalam tiga kelompok masa pendirian. Pertama, masyarakat sipil yang lahir pada masa Orde Baru. Kedua, masyarakat sipil yang lahir masa reformasi. Ketiga, masyarakat sipil yang lahir pada pasca reformasi.

Pada masa Orde baru, peneliti mengidentifikasi 2 masyarakat sipil yang lahir pada masa ini. Pertama adalah Dewan Perwakilan Cabang (DPC) Konfederasi Serikat Pekerja Seluruh Indonesia. Konfederasi ini lahir tahun 1973. Kedua adalah Jaringan Kemanusiaan Jawa Timur (JKJT) yang lahir 
pada 1996. Kedua, pada masa reformasi (1998-1999), ada dua masyarakat sipil yang dibentuk yaitu Mitra Wanita Pekerja Rumah Indonesia (MWPRI) dan Malang Corruption Watch (MCW). Sisanya sebanyak 11 masyarakat sipil lahir pasca reformasi yang berentang dari tahun 2002 sampai dengan tahun 2015.

Nampak jelas disparitas kelahiran masyarakat sipil di Kota Malang. Pada masa pemerintah Orde Baru hingga tahun 1999 ternyata pertumbuhan masyarakat sipil di Kota Malang tidak menggembirakan. Dikatakan demikian, karena hanya empat masyarakat sipil yang muncul pada periode ini. Hal ini menunjukkan potret buram pembentukan masyarakat sipil di Kota Malang pada masa sebelum reformasi. Pasca tahun 1998-1999 hingga sekarang, pertumbuhan masyarakat sipil mengalami kenaikan yang signifikan yakni 11 buah. Jumlah ini menunjukkan angin segar kehadiran masyarakat sipil dalam pentas politik lokal. Geliat masyarakat sipil di Kota Malang menunjukkan proses politik demokrasi sedang berjalan. Proses ini tentu perlu didukung dalam kerangka membangun demokrasi local yang mengharuskan terjadinya partisipasi publik yang luas dalam pembentukan dan pengawasan pelaksanaan kebijakan publik di tingkat lokal (Suyanto, 2014: 17).

Semakin kompleks kondisi masyarakat, semakin banyak permasalahan yang ada di Kota Malang, dan semakin terbuka pemerintah Kota Malang, maka semakin banyak masyarakat sipil yang ada di kota ini. Dari kelima belas masyarakat sipil yang diteliti, terpetakan beberapa isu yang diusung oleh masyarakat sipil tersebut. Isu-isu yang diusung sangat membumi dalam tata kelola pemerintahan daerah. Isu besar yang diusung yakni kesehatan, pendidikkan, buruh, pembangunan dan pemerintahan, perempuan, dan anak jalanan. Dari data yang diperoleh, terdapat masyarakat sipil yang hanya fokus pada satu isu, tetapi juga terdapat masyarakat sipil yang fokus lebih dari satu isu.

Masyarakat sipil yang bergerak dalam isu kesehatan adalah Yayasan Sadar Hati dan Sahabat Anak Kanker Malang. Masyarakat sipil yang bergerak di bidang pendidikan adalah Jaringan Kemanusiaan Jawa Timur, Save Street Child, Lembaga Pendidikan Sosial (LPS) Ibu Pertiwi, LKSA Harapan Umat, dan Aliansi Masyarakat Miskin Malang. Isu buruh di tingkat lokal juga banyak menjadi fokus asosiasi yang bergerak di tingkat lokal. Di Malang, yang fokus pada isu buruh adalah Malang Corruption Watch (MCW), In Trans Institute, dan DPC Konfederasi Serikat Pekerja Seluruh Indonesia.

Pada isu pembangunan dan pemerintahan, termasuk isu korupsi, tak luput dari sorotan masyarakat sipil di tingkat lokal. Di Malang yang fokus pada isu korupsi adalah MCW. Kehadiran MCW dengan menyuarakan isu pemberantasan korupsi sangat penting karena persoalan korupsi merupakan musuh kita bersama. Bahkan, dalam beberapa tahun terakhir, persoalan korupsi sudah menyebar secara luas dan terdesentralisasi secara sempurna ${ }^{1}$. Selanjutnya, permasalahan seperti ketidakmerataan pembangunan

\footnotetext{
${ }^{1}$ Muhtar Haboddin dan Fathur Rahman, Gurita Korupsi Pemerintah Daerah, Jogjakarta, Kaukaba, 2013; Ahmad Imron Rozuli, Muhtar Haboddin, dan Joko Purnomo (ed). Memahami Kompleksitas Korupsi, Malang: FISIP Press, 2016.
} 
maupun evaluasinya menjadi salah satu hal yang membuat masyarakat sipil di tingkat lokal tertarik untuk mendalaminya. Mereka yang bergerak di isu ini adalah PATTIRO, In Trans Institute, dan PPOTDA.

Isu tentang perempuan adalah isu lain yang pasti ada di setiap daerah. Di tingkat lokal, mereka yang fokus pada isu pemberdayaan perempuan adalah Mitra Wanita Pekerja Rumah Indonesia dan RUMPUN. Kekerasan dalam rumah tangga (KDRT) sering dialami oleh istri. RUMPUN tidak hanya sebatas memberdayakan perempuan, masyarakat sipil ini juga bergerak dalam isu KDRT.

Isu perempuan dengan segala problematikanya merupakan isu abadi yang selalu aktual. Perempuan pada tataran praktik selalu dijadikan objek kekerasan dan biasa menerima ketidakadilan dalam bidang pekerjaan. Karena itu dengan melakukan pembelaan kepada kaum perempuan diharapkan harkat dan martabatnya bisa sejajar dengan kaum pria. Karena itu, melalui masyarakat sipil pembedaayaan kepada kaum perempuan dalam bidang ekonomi, politik, hukum, dan budaya menjadi keharusan dan menjadi tanggungjawab negara untuk memberikan perlindungan (Arivia, 2006: 3) .

Isu tentang anak jalanan tidak hanya menjadi tugas pemerintah. Masyarakat Sipil melihat perlu adanya keterlibatan mereka dalam menangani masalah anak jalanan. Masyarakat sipil yang bergerak yang fokus dalam isu ini adalah Griya Baca, Save Street Child, dan Jaringan Kemanusiaan Jawa Timur.

Dana adalah hal yang sangat penting dan krusial bagi eksistensi sebuah organisasi masyarakat sipil. Walaupun masyarakat sipil ini bergerak dalam bidang nirlaba, mereka tetap membutuhkan dana untuk tetap dapat menjalankan program dan menggaji pengurus. Di Malang, terdapat beberapa macam cara yang digunakan oleh masyarakat sipil ini dalam mendanai program-program mereka. Berdasarkan temuan penelitian, terdapat enam sumber pendanaan, yaitu berasal dari donor pribadi, pemerintah dalam negeri, pemerintah luar negeri, non pemerintah dalam negeri, non pemerintah luar negeri, dan kegiatan usaha mandiri masyarakat sipil tersebut. Sebagian besar dari mereka mempergunakan lebih dari satu sumber pendanaan. Sebagai contoh masyarakat sipil mendapatkan pendanaan dari pemerintah daerah dan donor pribadi.

Ada beberapa hal yang mendasari mereka hanya memiliki satu sumber pendanaan. Pertama, masyarakat sipil ini masih muda dan belum ada legalitas sehingga sulit untuk memperoleh kerjasama pendanaan dari lembaga lain. Sebagai contoh adalah Sahabat Anak Kanker Malang dan Aliansi Masyarakat Miskin Malang. Kedua, masyarakat sipil ini mempertahankan posisi kemandirian lembaga. Asosiasi seperti ini contohnya adalah In Trans Institute dan DPC Konfederasi Serikat Pekerja Seluruh Indonesia. Ketiga, masyarakat sipil ini berusaha terus bekerja sama dengan pemerintah dan mendukung program pemerintah, contohnya adalah PPOtoda.

Masyarakat sipil yang memiliki dua atau lebih sumber pendanaan, merupakan kombinasi dari semua jenis pendanaan yang ada. Untuk melaksanakan program kerja, masyarakat sipil tidak cukup hanya mengandalkan dana dari usaha mandiri saja, melainkan perlu ada 
bantuan dana dari pihak lain, misalnya donor pribadi. Masyarakat sipil juga dapat bekerja sama dengan pemerintah, baik dalam negeri maupun luar negeri dalam hal pendanaan. Dari sisi non pemerintah, terdapat sektor swasta baik dalam negeri maupun luar negeri yang memiliki dana Corporate Social Responsibility (CSR) yang dapat diakses oleh masyarakat sipil di Malang. Selain itu, kerja sama antar masyarakat sipil, baik dalam negeri maupun luar negeri juga mampu memberikan sumber pendanaan program jika mereka memiliki isu yang sama.

Dari semua sumber pedanaan, berikut ini merupakan hasil identifikasi sumber pendanaan yang diterima oleh masyarakat sipil di Kota Malang. Untuk donor dari pemerintah dalam negeri, banyak anggaran dari APBN yang dapat dikucurkan untuk program masyarakat sipil. Pemerintah Daerah yang paling sering terlibat dalam pendanaan masyarakat sipil di Kota Malang adalah Dinas Sosial Kota Malang. Disusul Dinas perindustrian dan perdagangan dan Lembaga Zakat Kementrian Agama Malang. Di tingkat pusat, yang pernah terlibat dalam pendanaan masyarakat sipil di Kota Malang adalah Kementrian Sosial, Kementrian Pendidikan, Kedutaan Besar Jepang, dan Lembaga Zakat milik PLN.

Untuk lembaga non pemerintah di dalam negeri tercatat ada dua macam, yaitu pihak swasta melalui dana CSR. Dana CSR ini ada yang dikelola sendiri oleh perusahaan dan ada pula dana CSR yang dikelolakan kepada lembaga pengelola dana terpisah. Masyarakat Sipil di Kota Malang pernah menerima dana untuk operasional program kerja dari
Indonesian Parliament Centre, Yayasan TIFA, PT Sun Life, dan Rotary Metropolitan Jakarta Club.

Untuk pemerintah luar negeri, berbagai negara sudah pernah memberikan dana kepada masyarakat sipil di Kota Malang. Paling banyak adalah Amerika Serikat dan Australia melalui USAID dan AUSAID. Selain lembaga-lembaga penyandang dana perwakilan negara tadi, terdapat The Asia Foundation, European Foundation, ILO, UNIFEM, dan ASEAN Foundation yang juga pernah memberikan dana untuk program masyarakat sipil di Kota Malang.

Pada level internasional, banyak lembaga yang pernah terlibat dalam program kerja masyarakat sipil di Malang. Mereka terdiri dari dua macam, yaitu berasal dari swasta yang mendirikan lembaga penyandang dana dan sesama masyarakat sipil di negara lain. Penyandang dana yang berasal dari perusahaan swasta luar negeri adalah Global Fund, The Ford Foundation, Oxfam Hong Kong, Gate and Melinda Foundation. Penyandang dana yang berasal dari LSM dari uar negeri adalah Mercy Relief (Singapura), American Red Cross, Norwegian Red Cross, dan Save The Childrem (Amerika Serikat). Access, FNV, IWE, E-Homakers dan ISIF Asia Tenggara.

Usaha mandiri oleh masyarakat sipil di Malang dilakukan dengan iuran anggota, menjual hasil kerajinan anggotanya, membuat usaha percetakan, melakukan usaha ekspor, membuka jasa persewaan alat-alat dan menyediakan jasa fotografer. Semua ini dilakukan dalam kerangka mendapatkan pendanaan. 


\section{Kontribusi Masyarakat Sipil Malang dalam Pengembangan Demokrasi Lokal}

Hasil penelitian menunjukkan bahwa masyarakat sipil di Malang terbagi-bagi ke dalam banyak kelompok sesuai isu yang diusung. Dengan beragamnya isu ini, kontribusi mereka juga berbeda-beda. Isu yang diusung oleh masyarakat sipil diketahui berdampak pada jenis dan kedalaman kontribusi mereka, dengan demikian kontribusi masyarakat sipil akan dipaparkan berdasarkan isu yang diusung.

Isu kesehatan di Kota Malang diusung oleh Yayasan Sadar Hati dan Sahabat Anak Kanker Malang. Yayasan Sadar Hati memfokuskan pada penderita HIV AIDS, sedangkan Sahabat Anak Kanker Malang memfokuskan pada anak penderita kanker. Dari sisi pendanaan, karena Yayasan Sadar Hati jauh lebih lama berdirinya daripada Sahabat Anak Kanker Malang, maka pendanaan dan jaringan dari LSM ini lebih luas. Isu terkait HIV AIDS adalah isu internasional, sehingga mudah mengumpulkan banyak pihak yang mau terlibat atau bekerja sama.

Dalam siklus kebijakan, masyarakat sipil yang bergerak dalam isu kebijakan telah bisa terlibat dalam proses perencanaan dan implementasi kebijakan, namun belum sampai pada tahap evaluasi. Hal ini dapat dijelaskan dari posisi masyarakat sipil yang bermitra dengan pemerintah. Masyarakat sipil tidak menempatkan diri sebagai aktor yang kontra terhadap pemerintah karena masyarakat sipil di sini msih membutuhkan peran pemerintah dan tergantung dengan pemerintah. Hal ini di- buktikan dengan pengadaan jarum suntik dan alat kontrasepsi yang hanya bersumber dari pemerintah.

Di sisi yang lain, keberadaan masyarakat sipil merupakan pelengkap peran pemerintah dalam menjalankan tugas pelayanan publik, khususnya pelayanan kesehatan. Pelayanan kesehatan kepada ODHA dan pengguna narkoba dirasakan oleh pasien lebih "ramah". Pendekatan dan metode yang dipergunakan tidak langsung kontra, dengan kekerasan, atau dikriminalkan sehingga ODHA dan pengguna narkoba lebih berpartisipasi dalam proses penyembuhan. Masyarakat sipil pada isu kesehatan melakukan pemberdayaan masyarakat namun tidak melakukan kegiatan advokasi pada kasus yg bertentangan berlawanan dengan negara.

Karena masyakat sipil bergerak dalam isu kesehatan, yang artinya berusaha menolong orang sakit, masyarakat sipil masuk ke dalam tipe konformisme. Menurut Mansour Fakih (1996) tipe ini bergerak dalam bidang karitatif. Berbagai macam program yang dilaksanakan oleh amsyarakat sipil sifatnya adalah membantu.

Dalam konteks demokrasi di Kota Malang, Masyarakat sipil telah mampu membangun saluran di luar partai politik untuk mengartikulasikan, menampung dan merepresentasikan kepentingan, khususnya untuk menyediakaan akses bagi kelompok-kelompok marginal seperti penderita kanker, Lesbian, Gay, Biseksual, dan Transgender (LBGT), dan HIV AIDS. Masyarakat sipil juga dapat meminimalisasi polaritas konflik dalam masyarakat. Kelompk masyarakat yang menjadi sasaran dari Yayasan Sadar Hati selain pengguna narkoba adalah para 
LGBT karena kelompok masyarakat ini rentan terkena penyakit HIV AIDS. Masyarakat sipil menjadi jembatan yang memersatukan pemilahan kelas, etnis, agama, partisan terutama ketika menghadapi kekuasaan otoriter Negara.

Isu pendidikan merupakan isu yang dimiliki oleh banyak asosiasi sukarela di Malang. Semua memiliki program pemberian pelayanan pendidikan gratis kepada anak-anak dari keluarga tidak mampu. Dari banyak asosiasi sukarela yang memberikan pelayanan pendidikan kepada anak-anak ini, dapat diidentifikasi 2 asosiasi yang fokus utamanya pada dunia pendidikan, yaitu adalah Lembaga Pendidikan Sosial (LPS) Ibu Pertiwi dan Lembaga Kesejahteraan Sosial Anak Harapan Ummat (LKSA HARUM).

Masyarakat sipil yang bergerak dalam isu pendidikan melengkapi keberadaan negara, karena negara tidak mampu menyelenggarakan pelayanan pendidikan secara maksimal. Sebagai pelengkap dari keberadaan negara, masyarakat sipil bekerja sama dengan negara. Bahkan masyarakat sipil dipercaya oleh negara untuk melaksanakan tugasnya untuk memelihara anak terlantar (anak yatim piatu). Masyarakat sipil juga menjadi fasilitator bagi masyarkat sipil lain dalam pemberian standar pengelolaan panti asuhan.

Program-program yang dilaksanakan oleh masyarakat sipil bersifat karitatif, tidak bermuatan ideologis maupun politis. Tetap mempertahankan kerja sama dengan pemerintah karena pemerintahan dalah mitra. Masyarakat sipil pada isu pendidikan sama dengan isu kesehatan, merek melakukan pemberdayaan masyarakat namun tidak melakukan kegiatan advokasi pada kasus yang bertentangan berlawanan dengan negara. Masyarakat sipil ingin mempertahankan kemitraan dengan pemerintah daerah.

Dalam konteks demokrasi di Kota Malang, masyarakat sipil telah mampu membangun saluran di luar partai politik untuk mengartikulasikan, menampung dan merepresentasikan kepentingan, khususnya untuk menyediakaan akses pendidikan bagi kelompok-kelompok marginal seperti anak yatim dan orang miskin.

Isu buruh di Kota Malang diusung oleh MWPRI dan DPC Konfederasi Serikat Pekerja Seluruh Indonesia (KSPSI). DPC KSPSI merupakan masyarakat sipil yang mewadahi pekerja yang bekerja di industri. MPWRI khusus menangani isu buruh wanita yang bekerja di rumah. Sebagai contoh adalah wanita yang bekerja menerima pesanan pembuatan bordir, rokok, sepatu, pesanan konvensi, dan lain-lain.

Dapat disimpulkan bahwa masyarakat sipil dalam isu buruh di Kota Malang terbagi ke dalam dua model. Model pertama adalah yang diperjuangkan adalah permasalahan pokok (ekonomi), seperti UMK, bantuan hukum PHK sepihak, atau pemenuhan hak yang tidak diterima buruh. Model kedua adalah masyarakat sipil tetap memperjuangkan hak-hak ekonomi tapi sudah menjangkau permasalahan yang lebih luas. Sebagai contoh adalah penguatan organisasi dan jaringan, keamanan kerja, dan perlindungan hukum oleh pemerintah.

Dari sisi pendanaan, masyarakat sipil tidak ada yang bekerja sama dengan pemerintah dalam hal pendanaan. Pada titik ini, pemerintah sebagai pengambil kebijakan dituntut untuk memenuhi hak- 
hak buruh. Masyarakat sipil menjadi advokat yang menjembatani kepentingan buruh, sebagai contoh adalah pada penetapan UMK dan perlindungan pekerja.

Dalam konteks demokrasi di Kota Malang, masyarakat sipil mampu mendorong pemahaman tentang kewarganegaraan. Kedua, masyarakat sipil mampu membangun saluran di luar partai politik untuk mengartikulasikan, menampung dan merepresentasikan kepentingan, khususnya untuk menyediakan akses bagi kelompok buruh.

Pada isu pembangunan dan pemerintahan masyarakat sipil terbagi ke dalam dua kubu. Kubu pertama adalah kubu PP Otoda dan PATTIRO Malang. Kedua masyarakat sipil ini cenderung bekerja sama dengan pemerintah dalam pelaksanaan programnya. Kubu kedua adalah kubu MCW dan In Trans Institute. Kubu ini cenderung melawan pemerintah. Pada kubu yang melawan pemerintah ini mereka bersifat idependen. Hal ini terlihat dari cara pendanaan asosiasi yang tidak tergantung pada lembaga tertentu.

Masyarakat sipil pada isu pemerintahan ini masuk pada wilayah politis. Mereka mengagregasi kepentingan dan membuat tekanan politik terhadap peraturan-peraturan pemerintah. Caracara yang dipergunakan terdapat 2 cara. Masyarakat sipil dapat bekerja sama untuk memberikan perubahan pada pemerintahan seperti yang dilakukan oleh PP Otoda dan PATTIRO. Cara lain adalah dengan berkonfrontasi dengan pemerintah daerah seperti yang dilakukan oleh MCW.

Dalam konteks demokrasi di Kota Malang, masyarakat sipil mampu me- nyediakan basis pembatas kekuasaan negara. Kedua melengkapi peran partai politik dalam mendorong partisipasi. Ketiga, meningkatkan efektifitas dan ketrampilan berdemokrasi serta mendorong pemahaman tentang kewarganegaraan, mengembangkan proyek demokratisasi lewat pendidikan politik. Keempat, memantau proses politik. Keempat, membangun modal sosial di tingkat grassroot untuk bekerja sama mengatasi persoalan publik sehingga memperkuat fondasi demokrasi.

Masyarakat sipil yang berfokus pada isu perempuan adalah Ruang Mitra Perempuan (RUMPUN). Walaupun MWPRI menjadikan perempuan sebagai sasaran program-program mereka, MWPRI hanya melihat perempuan yang bekerja menerima order di rumah. RUMPUN melaksanakan berbagai macam program yang ditujukan kepada perempuan. Diantaranya adalah RUMPUN mengajak perempuan untuk hadir dalam kegiatan musrenbang, melakukan pemberdayaan ekonomi secara berkelompok, dan melakukan pelatihan untuk memotivasi kepercayaan diri perempuan desa.

Lebih dari 10 tahun berdiri, LSM ini telah mampu bekerja sama dengan berbagai pihak untuk menjalin kerja sama dengan berbagai pihak untuk pendanaan program. Pendanaan yang dilakukan oleh rumpun melalui tiga cara, pendanaan dari pemerintah Indonesia, pendanaan dari pemerintah luar negeri, dan pendanaan dari non pemerintah yang berasal dari luar negeri.

Isu perempuan, khususnya perempuan desa yang miskin dan berada di daerah tertinggal adalah isu bersama yang diusung oleh banyak lembaga. 
Didukung dengan kesetaraan gender adalah salah satu poin dalam Millenium Development Goal, mudah bagi masyarakat sipil untuk bekerja sama dengan berbagai pihak. Masyarakat sipil dalam isu perempuan bekerja sama dengan pemerintah dan non pemerintah, baik dalam negeri maupun luar negeri.

Masyarakat sipil dalam isu perempuan telah menemukan titik temu kerja sama, terutama dalam hal pemberdayaan ekonomi perempuan. Hal ini ditegaskan oleh Nila Wardani:

“...RUMPUN hanya mendekati kepada institusi-institusi pemerintahan, misalnya menekati kantor pemberdayaan perempuan dan anak untuk melinkkan ibu-ibu kepada pihak-pihak yang terkait. Dan Dinas Perdagangan seperti itu yang kita dekati..."

Dengan demikian, posisi masyarakat sipil di sini bermitra atau bekerja sama dengan pemerintah dan bekerja sama dengan pihak luar negeri. Isu perempuan sudah menjadi isu internasional, sehingga baik pemerintah dalam negeri maupun luar negeri, baik non pemerintah dalam negeri maupun luar negeri sama-sama berkomitmen untuk memajukan perempuan Indonesia.

Sama seperti pada isu kesehatan dan pendidikan, pada isu perempuan, masyarakat sipil melakukan pemberdayaan masyarakat namun tidak melakukan kegiatan advokasi pada kasus yang bertentangan berlawanan dengan negara. Cara-cara yang dipergunakan adalah tetap mempertahankan pada posisi kerja sama atau bermitra dengan pemerintah

\footnotetext{
${ }^{2}$ Wawancara dengan Nila Wardani, koordinator RUMPUN pada Mei 2016.
}

agar selalu mendapatkan pendanaan dari pemerintah.

Dalam konteks demokrasi lokal, masyarakat sipil mampu masyarakat sipil melengkapi peran partai politik dalam mendorong partisipasi. Kedua, meningkatkan efektifitas dan ketrampilan berdemokrasi serta mendorong pemahaman tentang kewarganegaraan, membangun saluran di luar partai politik untuk mengartikulasikan, menampung dan merepresentasikan kepentingan, khususnya untuk menyediakaan akses bagi kelompok perempuan.

Anak jalanan adalah salah satu isu utama di Kota Malang dilihat dari banyaknya asosiasi sukarela yang terlibat dalam penanganan terhadap anak jalanan. Bermula dari anak jalanan ini menyambung ke isu yang lain, sebagai contoh adalah pendidikan. Dengan demikian isu anak jalanan erat dengan isu pendidikan yang ditujukan khusus bagi anak jalanan. Program yang dilaksanakan kepada para anak jalanan ini semuanya memiliki 3 program yang sama, yaitu pemberian pendidikan di luar sekolah, bakti sosial, dan kegiatan non belajar.

Dari segi pendanaan, masyarakat sipil yang bergerak pada isu ini memiliki cara pendanaan program yang bervariatif. Cara pendanaan yang dilakukan adalah melalui usaha mandiri masyarakat sipil, menerima donor dari individu, menerima donor dari pemerintah dalam negeri, menerima donor dari lembaga non pemerintah luar negeri, dan lembaga non pemeritah dalam negeri. Masyarakat sipil pada isu ini belum mampu bekerja sama dalam pendanaan dengan pemerintah luar negeri. 
Terkait di bidang politik dan pemerintahan, dari keempat kelompok masyarakat sipil, tidak teridentifikasi adanya upaya-upaya secara politik berkaitan dengan anak jalanan. Masingmasing kelompok ini bekerja sendirisendiri, tidak ada pengorganisasian. Dapat disimpulkan bahwa dalam isu anak jalanan tidak ada jaringan yang mempersatukan mereka sehingga isu anak jalanan menjadi isu besar. Tidak ada konsorsium atau kerja sama antar masyarakat sipil yang bergerak dalam isu anak jalanan.

Isu anak jalanan selain terkait dengan isu pendidikan juga dekat dengan isu kesehatan, kemiskinan, dan kekerasan. Anak jalanan adalah kelompok masyarakat yang rentan terkenan tindakan kekerasan seksual, penyakit seksual, pekerja di bawah umur, kekerasan terhadap anak, dan lain-lain. Terdapat banyak asosiasi yang bekerja pada isu anak jalanan di Kota Malang namun tidak ada kerjasa sama atau jejaring antar asosiasi. Hal ini dapat diartikan bahwa walaupun isu ini penting, namun bukan mejadi isu prioritas oleh masyarakat sipil di Kota Malang.

Anak jalanan adalah salah satu dari kelompok Penyandang Masalah Kesejahteraan Sosial (PMKS), yang mana Dinas Sosial adalah instansi yang ditunjuk oleh pemerintah pusat untuk menangani permasalahan anak jalanan di tingkat lokal. Dari keempat asosiasi ini, tidak ada satu pun yang bekerja sama dengan Dinas Sosial. Pendanaan dari pemerintah membutuhkan pengajuan proposal dengan proses yang relatif rumit. LSM yang menerima dana untuk program harus membuat laporan pertanggungjawaban yang relatif rumit juga, seperti yang disampaikan oleh Tri Wijayanti berikut ini:

"Kalau dana itu kita harus buat proposal dulu, dan itu memang ribet banget. Makanya ga semua LSM mau ngajuin itu. Kalau udah dapet pun kita harus buat Laporan Pertanggungjawaban. LPJnya itu juga lebih ribet lagi. Itulah kenapa nggak semua LSM dapet dana itu ${ }^{3}$."

Dengan rumitnya proses tersebut, masyarakat sipil yang fokus pada isu anak jalanan ini lebih suka menjaring donasi dari donatur, khususnya donatur individu. Dengan adanya donor individu yang berganti-ganti, artinya tidak ada dominasi. Tidak adanya kerja sama pendanaan dengan pemerintah, baik dalam negeri maupun luar negeri. Tidak adanya kerja sama yang terus-menerus dengan lembaga donor tertentu memiliki dampak yang signifikan terhadap masyarakat sipil. Masyarakat sipil yang fokus pada isu anak jalanan ini akan lebih independen. Masyarakat sipil lebih bebas membuat program yang akan dilaksanakan untuk anak jalanan. Tidak ada program yang bersifat donor driven sehingga program yang dilaksanakan betul-betul mempertimbangkan kebutuhan anak jalanan.

Masyarakat sipil pada isu anak jalanan ini jumlahnya banyak. Mereka bergerak dalam program dengan paradigma karitatif. Hal yang tidak ideologis ini justru menarik donor-donor individu untuk menyumbangkan dana dalam pelaksanaan program. Karena masyarakat ini lebih independen, keberlanjutan dari program kerja akan lebih

\footnotetext{
${ }^{3}$ Wawancara dengan Tri Wijayanti, Ketua Griya Baca pada Mei 2016.
} 
terjamin. Dalam program yang bersifat karitatif ini masyarakat sipil hadir karena negara tidak hadir dalam manangani persoalan anak jalanan. Dalam hal ini masyarakat sipil mengambil alih peran negara, sama sekali tidak bekerja sama dengan negara, dan negara dianggap gagal dalam melaksanakan tugasnya memelihara anak-anak miskin dan terlantar ini.

Banyaknya jumlah masyarakat sipil yang bergerak pada isu masyarakat sipil ini ternyata tidak menjamin adanya kapasitas kolektif. Hal ini dikarenakan masyarakat sipil pada isu anak jalanan tidak memiliki modal sosial antar masyarakat sipil, tidak memliki trust antar masyarakat sipil, dan tidak berjaringan.

Masyarakat sipil dalam isu anak jalanan ini memusatkan perhatian pada pemberdayaan masyarakat, yaitu meningkatkan kesejahteraan anak jalanan dengan menyediakan pendidikan alternatif dan permainan. Masyarakat sipil tidak berminat melakukan kontak dengan pemerintah. Program-program yang dilaksanakan yang bersifat karitatif ini membuat masyarakat sipil masuk ke dalam tipe yang disebut oleh Manosur Fakih (1996) sebagai tipe konformisme. Dalam konteks demokrasi di Kota Malang, masyarakat sipil telah mampu membangun saluran di luar partai politik untuk mengartikulasikan, menampung dan merepresentasikan kepentingan, khususnya untuk menyediakaan akses pendidikan dan hiburan bagi kelompokkelompok marjjinal seperti anak jalanan.

\section{SIMPULAN}

Di Kota Malang terdapat banyak asosiasi sukarela. Pemerintah Kota
Malang tidak membatasi keberadaan dan isu yang dikaji oleh masyarakat sipil atau LSM di Kota Malang. Terdapat banyak isu yang menjadi fokus dari masyarakat sipil di kota Malang. Penelitian ini mendapatkan enam isu utama yang diusung oleh masyarakat sipil di Kota Malang, yaitu penanganan terhadap anak jalanan, isu kesehatan, isu pemerintahan, isu perempuan, dan isu buruh, dan isu pendidikan. Hal ini menunjukkan tidak ada isu khas Malang yang diusung oleh masyarakat sipil.

Masyarakat sipil yang bergerak dalam isu penanganan anak jalanan, kesehatan, dan pendidikan adalah LSM yang program kerjanya karitatif, minim muatan ideologis dan politis. Hal ini membuat LSM masuk ke dalam tipe konfronmisme. Masyarakat sipil yang bergerak dalam bidang pemerintahan terbagi ke dalam 2 tipe yaitu tipe reformis dan tipe transformatif. Masyarakat sipil tipe reformis mempromosikan reformasi tata kelola pemerintahan yang berasal dari lembaga donor luar negeri. Program yang dilaksanakan berasal dari lembaga donor dan tidak sesuai kebutuhan masyarakat. Masyarakat sipil tipe transormatif membuat sekolah-sekolah ideologi anti mainstream yang ditujukan kepada masyarakat.

Dari sekian banyak asosiasi sukarela di Kota Malang, hampir tidak ada/jarang sekali kerja sama antar asosiasi sukarela. Artinya masyarakat sipil hanya bekerja sama dengan pihak yang memungkinkan memberi pendanaan. Masyarakat sipil kurang mampu berjejaring sesama mereka dan fokus pada isu masing-masing. 


\section{DAFTAR PUSTAKA}

Arivia, Gadis. (2006). Feminisme Sebuah Kata Hati. Jakarta, Kompas.

Chandoke, Neera. (2002). Benturan Negara dan Masyarakat Sipil. Yogyakarta, Tiara Wacana

Diamond, Larry. (1994). Rethinking Civil Society. Journal of Democracy 5

El Medni, Bakry M. (2013). Civil Society and Democratic Transformation in Contemporary Egypt: Premise and Promises. International Journal of Humanities and Social Science: Vol. 3 No. 12 [Special Issue - June 2013] Retrieved from https://www.ijhssnet.com/journals /Vol_3_No_12_Special_Issue_June_2 013/2.pdf

Fakih, Mansour. (1996). Masyarakat Sipil untuk Transformasi Sosial. Yogyakarta, Pustaka Pelajar.

Haboddin dan Rahman. (2013). Gurita Korupsi Pemerintah Daerah. Yogjakarta, Kaukaba.

Hikam, .A.S. (1996). Demokrasi dan Civil Society, Jakarta, LP3ES.

Jordan dan Tujil (ed. (2006). Akuntabilitas LSM, Jakarta, LP3ES.

Lee, Verena Beittinger. (2009). (Un) Civil Society and Political Change in Indonesia. USA, Routledge.

Lowry, Cameron. 2008. Asia Pacific Governance and Democracy Initiative. Retrieved form http://www.eastwestcenter.org/file admin/resources/research/PDFs/C ombined_country_reviews.pdf

Luth, Thohir. (2002). Masyarakat Sipil Solusi Damai dalam Perbedaan, Jakarta, Media Cita.

Mas'oed, Mohtar. (2002). Peran civil Society sebagai mitra kerja pemerintah dan Dunia Usaha dalam Mewujudkan Good Governance" dalam Azhari dkk (ed). Good Governance dan Otonomi Daerah. Jogjakarta: PKPEK dan Forkoma MAP-UGM.

Moleong, Lexy. (2004). Metode Penelitian Kualitatif, Bandung, Remaja Rosdakarya.

Prastowo, Andi. (2011). Metode Penelitian Kualitatif dalam Perspektif rancangan Penelitian. Yogyakarta, Ar Ruz Media.

Rahayu dan Trisnanto. 2016. Klientelisme dalam Birokrasi di Kota Blitar dan Kabupaten Malang. FISIP Universitas Brawijaya Malang

Risley, Amy. (2015). Civil Society Organization, Advocacy, and Policy Making in Latin American Democracies. United States, Palgrave Macmillan.

Rozuli, Haboddin, dan Purnomo (ed). (2016). Memahami Kompleksitas Korupsi. Malang, FISIP Press.

Stepan, Alfred. (1996). Militer dan Demokratisasi, Jakarta: Grafiti.

Sudibyo, Agus, 'Masyarakat Warga dan Problem Keberadaban', JSP, Vol. 14, No.1 Juli 2010, hlm. 23

Suharko, 'Masyarakat Sipil, Modal Sosial, dan Tata Pemerintahan yang Demokratis', JSP, Vol.8. No.3, Maret 2005, hlm.282

Suyanto, Djoko. (2014). Demokrasi Kita: 8 Pemikiran Politik, Jakarta, KPG.

\section{PROFIL SINGKAT}

Penulis merupakan Dosen di Program Studi Ilmu Pemerintahan FISIP Universitas Brawijaya Malang. Selain pengajar penulis aktif sebagai peneliti 